\title{
Ken Parry (ed.)
}

The Willey Blackwell Companion to Patristics. Chichester: Willey Blackwell, 2015, p. xvi, 530. ISBN 978-1-118-43871-8.

In our Internet century, it would be useless to enumerate all the 33 contributions of the equal number of authors, which form this volume. Instead, I would prefer to draw the main "lines of force."

The editor Ken Parry explains in ch. 1 ("The Nature and the Scope of Patristics") why this project "is not another patrology": "It focuses on the reception history of a selection of Fathers in order to show how their writings and their reputations were viewed down the centuries" (p. 3). In fact, I would add, such an approach implies that the book is focused on the problems most discussed in scholarship of the three latest decades. It could be used as an "update" to the earlier patrologies. ${ }^{1}$

Some chapters are written by most renowned scholars in their respective fields. In such cases, it is always difficult to discern whether we are dealing with a succinct exposition of author's life-long work or development of his/her investigations, because any new presentation made by the author him- or herself is also a step in further research. I consider such chapters the most valuable parts of the book. I will enumerate 13 among them according to my own choice, perfectly realizing that the choice of somebody else could be somewhat different: "Byzantine Florilegia"2 (ch. 2, Alexander Alexakis, pp. 16-50; an unavoidable topic in all patristic researches), "Origen of Alexandria" (ch. 6, Mark Edwards, pp. 98-110; short but dense), "Ephrem of Nisibis" (ch. 8, Andrew Palmer, pp. 126-140; also very dense and extremely good balanced between East and West), "John Chrysostom" (ch. 9, Wendy Mayer, pp. 141-154; a true sea map for this ocean-like domain), "Augustine of Hippo" (ch. 10, Kazuhiko Demura, pp. 155-169; includes, among others, Augustine's reception in China and Japan since the 16th cent.), "Shenute of Atripe" (ch. 12, Janet Timbie, pp. 184-196; with a special attention to the recent discussions and open questions), "Dionysius the Areopagite" (ch. 14, István Perczel, pp. 211-225; to my opinion, the most important author presently studying the history of the Corpus Areopagiticum, even though we continue with him a friendly polemic on the authorship), "Gregory the Great" (ch. 16, Bronwen Neil, pp. 238-249; one of the Popes of Rome especially important for Patristics), "Gregory of Narek" (ch. 19, Abraham Terian, pp. 278-292; with a special attention to the dogmatic controversies,

1 Which is described in ch. 3 "Modern Patrologies" by Angelo Di Berardino, pp. 51-67.

2 I would recommend to read together with ch. 27 "Fathers and the Church Councils" by Richard Price (pp. 400-413), where the topic of florilegia is among the first-plan ones. 
including an audacious hypothesis of the etymology of "T'ondrakeans" from the Dionysian term $\theta \varepsilon a v \delta \rho(x o ́ s)$, "The Iconophile Fathers" (ch. 23, Vladimir Baranov, pp. 338-352; with a discussion of the acute problem of the 8th-cent. sources and including the less known quarrels in the late Byzantium), "Hagiography of the Greek Fathers" (ch. 25, Stephanos Efthymiadis, pp. 370-384; a concise but rich review from Athanasius to Gregory Palamas), "The Fathers and the Reformation" (ch. 29, Irena Backus, pp. 428-441; I would recommend as a good guide of the post-15th-cent. Orthodox traditions for students), "The Fathers in Arabic" (ch. 30, Alexander Treiger, pp. 442-455; extremely helpful and includes some data recently discovered by the author).

There are two especially interesting chapters dedicated to the Greek and the Latin of the Fathers (ch. 31-32, by Klaas Bentein and Caroline White, respectively, pp. 456-470 and 471-486); they would be useful in particular to those who start to read Patristic texts in these languages. As a specimen of quite modern approaches to Patristics ch. 33 "Reimagining Patristics: Critical Theory as a Lens" by Kim Haines-Eitzen (pp. 487-496) concludes the book; she demonstrates achievements and perspectives of the post-structuralist method. Indeed, there are other new methods applied to the Patristic studies, but it is good to have an outline of, at least, one of them.

The chapter on Maximus the Confessor by Andrew Louth (ch. 17, pp. 250263) is perhaps less than one could expect reading about "a Major Modern Father" (as Ken Perry called Maximus in the title of the section dedicated to his outstanding place in the actual Patristic research, pp. $5^{-6}$ ). Being a review of the most known publications, it avoids less-evident topics in either history of reception ${ }^{3}$ or Maximian theology. It is difficult to explain a sentence like the following, confusing into a unique body such opposite authors as Jean-Claude Larchet, on the one hand, and Demetrios Bathrellos or Nikolaos Loudovikos, on the other: "What is striking about these Orthodox contributions to Maximian scholarship is that, without any detriment to their scholarly rigour, these treatises are also works of engaged theology" (p. 26o). A leitmotiv of Larchet's criticisms towards the scholars influenced by John Zizioulas's theology, including Bathrellos and Loudovikos, is precisely this: inadequacy of their understanding of Maximus caused with their theological agenda. ${ }^{4}$ We can take any

3 E.g., the role of metropolitan of Venice Gerasimos Vlachos as an assistant of Combefis and, through his disciples brothers Leichudes, the Maximian impact on the late 17th- and early 18th-cent. Orthodox thought. Cf. G. Podskalsky, Griechische Theologie in der Zeit der Türkenherrschaft (1453-1821). Die Orthodoxie im Spannungsfeld der nachreformatorischen Konfessionen des Westens, Munich, 1988, pp. 249, 276-281.

4 Cf. J.-Cl. Larchet, Personne et nature. La Trinité - Le Christ - L'homme. Contributions aux dialogues interorthodoxe et interchrétien contemporains (Théologies), Paris, 2011, passim but esp. 
side or no side here, but it is simply impossible to apply with an equal success the same criteria of good scholarship to such different kinds of studies as those of Larchet and Bathrellos.

In a very informative chapter on Clement of Alexandria by Piotr AshwinSiejkowski (ch. 5, pp. 84-97) a long paragraph dedicated to the so-called "Secret Mark" (p. 93) could be either much shorter or much longer. In the present state - without the most important references to recent studies ${ }^{5}$ it seems to me unbalanced in the favour of the partisans of the authenticity, whereas their voice is in fact not anyhow strong.

These notes of disagreement are, however, quite subjective. Among the certainly objective weaknesses of the book, I would not enumerate anything more significant than errors in transliterations of the titles in Russian, omissions of some page numbers in the index, or the systematic misspelling of the Wallonian family name "van Esbroeck" in a Flemish way as "Van Esbroeck." The collective work under review managed to snapshot how the first line of Patristic studies looked like in 2015 .

\section{Basil Laurié}

National Research University Higher School of Economics (HSE), Perm -

St. Petersburg hieromonk@gmail.com

p. 214, n. 31. Cf. also Larchet's review of Bathrellos's 2004 monograph (referred to by Louth) in Revue d'histoire ecclésiastique 101 (2006), pp. 202-205.

5 Esp. S.C. Carlson, The Gospel Hoax: Morton Smith's Invention of Secret Mark, Waco, TX, 2005; P. Jeffery, The Secret Gospel of Mark Unveiled: Imagined Rituals of Sex, Death, and Madness in a Biblical Forgery, New Heaven - London, 2007; for an exhaustive review of the currently available positions, s.: Ancient Gospel or Modern Forgery? The Secret Gospel of Mark in Debate. Proceedings from the 2011 York University Christian Apocrypha Symposium, ed. T. Burke, Eugen, OR, 2013. 